\title{
South African and Singaporean exporters: their attitudes, information sources and export problems
}

\author{
Steven M. Burgess* \\ Henley MBA Programme, Graduate Institute of Management and Technology, P.O. Box 4437, Rivonia, 2128 Republic of South Africa \\ Nicola Oldenboom \\ School of Economic and Business Studies, University of the Witwatersrand, P.O. Wits, 2050 Republic of South Africa
}

Received February 1997

\begin{abstract}
South Africa's emergence from years of political and regulatory trade barriers has focussed attention on South African exporters. In a replication of Elliot \& Krasnostein's study of 54 Singaporean exporters, the perceptions, attitudes and characteristics of a representative sample of 321 experienced South African exporters and their decision makers were investigated. Consistent with other international studies, the results suggest that managerial, organizational and environmental forces and perceptions motivate export behaviour. However, South African firms clearly are responding to unique situational factors and national export resources as well. The findings indicate that managerial leadership, supportive attitudes and extensive exporting experience are widely available in South Africa. Secondary information sources could be improved and freight costs reduced to improve South African export effectiveness.
\end{abstract}

\begin{abstract}
Suid-Afrika se bertoetrede tot die internasionale ekonomie na jare van politiese en regulerende handelsversperrings het Suid-Afrikaanse uitvoerders opnuut onder die soeklig laat kom. In navolging van 'n studie deur Elliot \& Krasnostein oor Singapoerese uitvoerders, ondersoek hierdie artikel die persepsies, houdings, en eienskappe van 321 ervare SuidAfrikaanse uitvoerders en hulle besluitnemers. In ooreenstemming met internasionale navorsing dui die resultate van dié studie daarop dat bestuurs-, organisatoriese, en omgewingsfaktore en persepsies uitvoergedrag beïnvloed. Die Suid-Afrikaanse firmas reageer egter ook op hul unieke situasie en op die bestaande nasionale hulpbronne vir uitvoerdoeleindes. Die resultate dui daarop dat bestuursleierskap, ondersteunende houdings en uitgebreide uitvoerervaring wyd beskikbaar in Suid-Afrika is. Sekondêre inligtingsbronnne kan verbeter word en vervoerkoste verminder word om Suid-Afrika se uitwoerdoeltreffendheid te verhoog.
\end{abstract}

*Author to whom correspondence should be addressed.

Many international companies, especially high-tech companies, have established a South African market presence since the election of the Government of National Unity, according to frequent popular press reports. South Africa may contribute only $0.5 \%$ of world-wide GDP (World Bank, 1996: 211), but strategic location and developed infrastructure make South Africa an attractive market and an inviting base for sub-Saharan or Indian Ocean Rim operations. Entry by new competitors and the rapid repeal of protective regulations are well known to impact on rivalry within an industry (for example Porter, 1980: Chapter 1). The entry of so many firms after years of isolation suggests a challenging new competitive environment which may well compel many South African firms to seek growth in international markets.

Regularly reported export and import trade statistics are available from reliable sources in South Africa but little international trade research has appeared in peer-reviewed academic journals concerning South Africa (notable exceptions include Dichtl, Leibold, Koeglmayr \& Mueller, 1983 and Viviers, Kroon \& Calof, 1996). No one has suggested a crisis; but it is important to note that Czinkota \& Johnston (1983) maintained that American export problems of the late 1970s and early 1980s were preceded by a crisis in international trade research. South African companies seeking growth will learn from the dynamic and increasingly internationalized home market. However, opportunities in international markets - now free from the legal and political impediments of previous decades - may demand new and unexpected competencies to compete effectively. Academic research plays an unbiased role in identifying and exploring key issues in this new environment.

The desire to better understand the contributory factors underlying export success and interest in Singapore's success in world trade were the impetus for this study. Singapore's emergence as a wealthy nation during the past two decades mainly as a result of manufacturing and trading prowess (Elliot \& Krasnostein, 1990; Wee Chow Hou, 1993) - interests many South African exporters. Despite the obvious geographical and population size differences, the two countries share many important cross-cultural, developmental and infrastructural characteristics. Importantly, both are located strategically in the emerging Indian Ocean Rim. International export research has linked export success to firm and decision-maker characteristics, export information sources, reasons for exporting and exporting attitudes and perceptions among many other characteristics (compare Aaby \& Slater, 1988; Bilkey, 1978; Cavusgil \& Nevin, 1981; Cunningham \& Spiegel, 1971; Eshghi, 1992). The current research (1) examines these concepts and their relationships in a representative sample of South African exporters, (2) compares the findings to Elliot \& Krasnostein's (1990) study of Singaporean research and development-based manufactured goods exporters, (3) provides a foundation for more focussed explorations suggested by the findings and (4) contributes to the international literature concerning exporting in developing nations. It is not the purpose of the current research to establish causal links between the various attitudes, firm characteristics and export performance or to link firms with stages in an export adoption process model. 


\section{Literature review}

There are many comprehensive reviews of the export literature (i.e. Aaby \& Slater, 1988; Bilkey, 1978; Morrison \& Inkpen, 1991). Although such reviews conclude that successful exporters and export managers exhibit certain characteristics, competencies, perceptions and attitudes, the quantum of research including developing nation exporters often is insufficient to allow prudent application of the findings to exporting in the developing world. The following brief review of selected contributions to the literature highlights the importance of concepts included in the current research.

\section{Firm characteristics}

Many firm characteristics have been studied in the literature. Although results sometimes have been indeterminate, there is little doubt that firm characteristics influence exporting performance. Firm size may not be an important factor in exporting success, as the success of Germany's small and mid-size exporters demonstrates. Nevertheless size contributes to factors such as financial strength and scale economies that influence competitive advantage (Aaby \& Slater, 1988: 21). Lack of size may lead to administrative problems impacting on export success such as problems handling export documentation (O'Rourke, 1985: 27).

Years in exporting may influence exporting success when a relatively stable export environment provides the opportunity for cumulative learning (Daniels, 1971; Louter, Ouwerkerk \& Bakker, 1991; Snavely. Weiner, Ulbricht \& Enright, 1964; Welch \& Wiedersheim-Paul, 1978). Keng \& Jiuan (1989) suggest that younger firms are more interested in foreign markets than older more established ones.

\section{Export stages}

The idea that firms transit identifiable stages of involvement to ultimate export commitment, after early stages of progressive export experimentation, stimulated much research in the 1970s and 1980s. Among the many export adoption models proposed, Cavusgil's (1980) export adoption process model has been very influential (see the discussion in Viviers $e t$ al., 1996: 35). Export involvement is considered to be a major influence on export success and usually is measured by comparing export sales to total sales (export intensity). Firms with an export intensity greater than $50 \%$ have been described as high involvement exporters (Diamantopoulos \& Inglis, 1988: 53).

Export intensity, attitudinal scales and analyses of resource allocation by the firm all have been used to measure the ultimate stage of commitment. Increased commitment by managers and companies has a positive influence on export performance (Aaby \& Slater, 1988: 17). Committed managers hold more positive perceptions and attitudes toward exporting and expect exporting to contribute to increased firm growth (Ali \& Swiecz, 1991: 74). Committed firms are more likely to allocate specific human and financial resources or to establish a separate export department (Cavusgil \& Nevin, 1981: 115). It is also important to note that committed firms can become exposed to increased foreign exchange rate fluctuation risk. although smaller firms may be less affected by this problem (Cavusgil, 1984: 204). Cavusgil (1984: 198) classified firms exporting less than $10 \%$ of total output as experimental exporters and those exporting more than $40 \%$ of total output as committed exporters.

Singapore's trading success has attracted a large number of multinational firms intent on exporting to affiliates - so many that Keng \& Jiuan (1989: 32 ) reported that $44 \%$ of Singaporean exporters had some foreign equity. Bilkey (1978: 37) suggests that a large proportion of exports to affiliates in foreign countries may indicate the ultimate current stage of a firm's export process. Altogether 39 of the 53 Singaporean firms reporting sales derived from exports indicated that over $50 \%$ of sales were derived from exports - an export intensity characterizing these firms as involved or committed using the traditional definitions above.

There is some concern about using traditional measures, such as export intensity, to characterize the involvement or commitment of South African firms (see Viviers et al., 1996: 38).

The qualitative research participants consistently expressed four notions that caused us to question the reliability of traditional operational concepts of involvement and commitment. The following four paragraphs capture the essence of these notions:

1. South African exporters were hindered by unique political and regulatory impediments in recent decades. These impediments were withdrawn swiftly in an environment of great political and socio-economic uncertainty in the home market during the year prior to the research. Relatively new exporters generally indicated that their firms were responding to the repeal of regulatory barriers by taking dramatic steps indicative of high involvement or commitment, such as setting up foreign sales offices.

2. Political and regulatory barriers often made it very difficult to open foreign trading offices and local foreign exchange controls further limited foreign investment opportunities. These conditions contributed to an extraordinary concentration of company ownership in the home market featuring the common adoption of strategic business unit (SBU) and divisionalized organizational structures. Most exporters operated from export departments (a sign of commitment to exporting), often in divisions selling a range of products from a group of companies. Although export managers knew the sales of their department and their ultimate group holding company, they often could not accurately quantify their proportions of intermediate divisionalized company sales. Participants indicated that exports represented a small proportion of group company sales but that exports probably represented a more significant proportion of sales in certain individual divisionalized companies with the group.

3. Qualitative research suggested that a culture of secrecy concerning export sales developed over the decades due to fear of becoming a sanctions target. One common response appears to have been active export through intermediaries. Most of the exporters participating in the qualitative phase reported that such sales occurred but few could quantify them. Further, many participants reported resentment that such sales often were considered domestic sales for reporting purposes.

4. Considering the nature of the political sanctions exporters faced, the failure to attain export sales exceeding $40 \%$ of 
total output could be expected in many industries even when the level of commitment or involvement was equal to that of other international firms. Many South African companies have exported successfully for decades but political and regulatory barriers precluded export to many markets (over $25 \%$ of respondents in the current research reported exporting for more than 15 years and about twothirds reported exporting more than five or more years). Success in the countries which did not participate in political sanctions was unlikely to lead to meaningful global market shares or to significantly increased overall sales.

These four notions were held almost universally by the qualitative participants. As a result, it was decided that the identification of export stages would not be a focus of the research but rather should be the focus of another devoted study. The South African Foreign Trade Organisation (SAFTO) senior managers participating in the qualitative research suggested that the characteristics and export experience of dues-paying full members were such as to suggest export commitment in most cases. Using an alternate view to adjust for the unique post-sanctions environment, if an export intensity of $10 \%$ is arbitrarily considered as a measure of export commitment and an export intensity of $5 \%$ is considered as an indicator of involvement, then $41 \%$ reported commitment in the current research and $53 \%$ reported involvement or commitment (see Table 1).

\section{Manager characteristics}

Many studies have shown that involved and committed managers are more likely to succeed in exporting (see Aaby \& Slater, 1988: 17). The literature suggests that visiting or living in foreign markets is a positive influence on export performance and that younger, more educated managers have the strongest foreign market orientation (Axinn, 1988; Dichtl et al., 1983). When compared to non-exporters, export managers are less fearful of taking risks or overcoming communication differences (Dichtl et al., 1983: 8).

\section{Reasons for exporting}

The genesis of the export decision can be internal or external to the firm (Johnston \& Czinkota, 1982). The most common source of exporting opportunity awareness is the receipt of unsolicited orders (Kaynak \& Kothari, 1984; O'Rourke, 1985; Pavord \& Bogard, 1975) and even this may not be a sufficient impetus to begin exporting (Dichtl et al., 1983: 8). Excess capacity (Brooks \& Rosson, 1982; Cavusgil, 1984; Johnston \& Czinkota, 1982; Korth, 1991) and sluggish sales in home markets (Pavord \& Bogard, 1975) also are often cited motivations.

The potential for increased profits or economies of scale can be important internal motivators. Although exporting often leads to higher profits and sales (Johnston \& Czinkota, 1982), it has been argued that this is not always a sufficiently strong incentive to enter into new markets (Cooper, Hartley \& Harvey, 1970; Hunt, Froggatt \& Hovell, 1967; Pavord \& Bogard, 1975).

The belief that exporting is in the national interest may be a fundamentally important top management attitude in exporting firms (Pavord \& Bogard, 1975: 6), but the link between this attitude and behaviour is inconsistent (Eshghi, 1992: 48).
Other less important motivators include enquiries from third parties, export assistance and incentives from foreign sources (Kaynak \& Kothari, 1984) and opportunities found while travelling in foreign markets (Pavord \& Bogard, 1975: 7). Managers may gain personal satisfaction in dealing with foreign customers. However, it appears that the need to improve the firm's image is not always a major incentive to export (Pavord \& Bogard, 1975: 8).

\section{Intormation sources}

Once the decision to consider exporting is made, information must be obtained to evaluate alternative export opportunities and formulate strategic plans. Decision makers generally rely on personal observation, contacts with foreign buyers and other primary information sources after having consulted secondary data sources (Cavusgil, 1985; Czinkota \& Ronkainen, 1993). Elliot \& Krasnostein (1990) found institutional sources to be unimportant although trade and industry publications (along with trade shows) are important information sources in the experimental and active export stages (Cavusgil, 1984). Foreign buyers can play an important role in estimating foreign market potential (Cavusgil, 1985; O'Rourke, 1985) and provide specific information required by the firm (Denis \& Depelteau, 1985: 12).

Generally, the literature suggests that committed exporters rely less on secondary information sources, such as governmental information, and feel less satisfied with the services provided by government departments (Denis \& Depelteau, 1985; Keegan, 1967; O'Rourke, 1985; Pavord \& Bogard, 1975; Tseng \& Yu, 1991) although Sood \& Adams (1984) would suggest otherwise.

\section{Problems}

Elliot \& Krasnostein (1990: 28) reported that very few problems presented major limitations to Singaporean firms and concluded that this was an indication of the internationalization of the firms and their commitment to exporting. Small firms have reported problems with export administration and export managers often have reported problems with human resources, logistics and acquiring information. Exporters encounter unique problems that require specialized skills and knowledge (Pavord \& Bogard, 1975: 7).

Human resource problems in exporting generally concern identifying suitable distributors in foreign markets (Cavusgil, 1984; Keng \& Jiuan, 1989), overcoming labour scarcity or recruiting suitable export management (Aaby \& Slater, 1988; Bilkey, 1978; Keng \& Jiuan, 1989). Identifying suitable foreign agents emerged as the second most reported major limitation for Singaporean firms (Elliot \& Krasnostein, 1990). Firms may adapt to difficulty finding foreign agents by improving skills concerning staff recruitment in foreign markets. Managers also can design technical solutions, such as expert systems, to overcome skilled labour shortages. Spreading export management responsibilities over a number of departments is another organizational strategy firms can employ to cope with human resource constraints (Diamantopoulos \& Inglis, 1988: 55).

There is evidence that the inability to meet foreign competitor pricing is a major limitation for exporters (Elliot \& 
Krasnostein, 1990; Keng \& Jiuan, 1989). Inefficient logistics systems also can impact on the firm's ability to meet demanding delivery time requirements forcing firms to adapt the marketing mix to accommodate for inefficiency (Kaynak \& Kothari, 1984: 65). High freight costs can be an important barrier to internationalizing the marketing effort ( $O$ 'Rourke, 1985). Acquiring inadequate information can be a major limitation to exporting success (Keng \& Jiuan, 1989).

\section{Mothod}

\section{Questionnaire}

Elliot \& Krasnostein (1990) was chosen as a starting point for the research after a literature review indicated that their study had measured the concepts of interest and after interviews with senior officials of the South African Institute of Marketing Management and SAFTO had indicated a high level of interest in understanding South African exporters from the same perspective. Each concept measured by Elliot \& Krasnostein (1990) was included in an initial draft questionnaire after small changes were made to effect consistency with normal South African grammar and spelling. The draft questionnaire was then discussed with senior managers in the SAFTO Research Department and more than 50 executives attending five South African Institute of Exporting strategic export marketing management seminars at SAFTO. This qualitative research evaluated the questions relating to sources of information, perceived export problems, and attitudinal statements.

Five reasons for exporting tested by Elliot \& Krasnostein (1990) were dropped because they were reported to be unlikely during the qualitative research. For instance, few South African banks abroad reported sales leads to South African exporters. Two reasons for exporting were added when they emerged regularly from the qualitative research.

Based on the qualitative findings, only six of the eight information sources tested by Elliot \& Krasnostein (1990) were retained in the current research. Ten additional information sources were noted for inclusion.

Six problem statements were dropped from the study when the qualitative research indicated that they did not occur because of structural or environmental differences between the two countries. For example, the statement concerning a firm's ability to offer competitive credit terms was dropped because of constraints in this regard imposed by foreign exchange regulations. Seven exporting problems were added to measure difficulties understanding foreign culture and business practices, political problems, transportation, sanctions and receiving payment which emerged as important problems in the qualitative research.

Seven statements about exporting tested by Elliot \& Krasnostein (1990) did not apply and were discarded. For example, the statement suggesting that exporting should only be considered after receipt of a written order was dropped because South African exchange control regulations require proof of a written order prior to fulfilment of an export order. Other attitudinal statements were dropped because over $80 \%$ of the Singaporean sample disagreed with the statements and the qualitative research indicated that a similar South African result was likely. Additional statements concerning attitudes about risk avoidance, market analysis, marketing effort and profit expectations were included after they emerged in the qualitative research.

A questionnaire more appropriate for South African respondents emerged from this qualitative research. The final questionnaire included eight pages comprising seven sections. The questionnaire was posted to the SAFTO membership list. SAFTO is the largest private export promotion institution in South Africa. It was founded by business community leaders in 1963 and recently became an affiliate of the Industrial Development Corporation. The 1300 member companies, varied in size and industry and located across all provinces of the country, are principally involved in manufacturing and were actively involved in exporting at some time during the past five years. Respondents were allowed five weeks to respond by post. Altogether 321 questionnaires $(25 \%)$ were returned.

The pre-addressed return envelope included a return address card which identified the respondent firm for sample composition analysis. To reduce response bias, respondents were not asked to identify themselves or their company on the questionnaire. Respondents came from a broad cross-section that is representative of SAFTOs membership. No attempt was made to match firms and questionnaires.

\section{Sample}

Both samples included firms exporting high technology products and services, although the South African sample also included some manufacturers of a wider range of goods. There was no significant difference (probability of $X^{2}>0.05$ ) between the two samples concerning exporting status, years exporting or number of employees. Approximately $95 \%$ of both samples were actively involved in exporting at the time of the study.

There were significant differences concerning other sample characteristics. A larger proportion of the South African sample had been established 4-5, 11-15 or over 20 years or teported annual sales of R1-R2 million or exceeding R20 million. Singaporean firms were more likely to have foreign ownership or to derive more than $50 \%$ of sales from exports. South African managers were older and were more likely to have not lived abroad. Singaporean managers were less likely to have been born on local soil or to have made no trips abroad. They were more likely to have lived abroad for less than a year and to have travelled overseas more than five times.

Elliot \& Krasnostein (1990) noted that the modal or typical firm in the Singaporean study was newly established or newly arrived in Singapore, was foreign-owned, employed more than 500 people, had annual sales in excess of $\$ \$ 40$ million and derived more than $75 \%$ of sales from exporting. Bearing in mind the lack of divisionalized financial reporting by South African exporters, the typical firm studied in the current research was over 20 years old, had been exporting more than six years, was locally-owned, had annual sales over R20 million and derived less than $5 \%$ of annual sales from exporting. 

Table 1 Characteristics: South African and Singaporean
exporters

\begin{tabular}{|c|c|c|c|c|c|}
\hline \multicolumn{6}{|c|}{ Country } \\
\hline & & Singepore & South Africa & Prob of $X_{2}$ & Cramer's V \\
\hline \multirow[t]{3}{*}{ Stanus } & Currast exp & $94 \%$ & $97 \%$ & 0.1179 & 0.1069 \\
\hline & Previous ap & $2 \pi$ & $3 \%$ & - & - \\
\hline & Never exp & $4 \%$ & $1 \%$ & - & - \\
\hline \multirow{9}{*}{$\begin{array}{l}\text { Yean } \\
\text { Estublistod } \\
\text { in this country }\end{array}$} & 0 & $0 \%$ & $1 \%$ & 0.0000 & 0.3578 \\
\hline & 1 & $6 \%$ & $3 \%$ & - & - \\
\hline & & $11 \%$ & $2 \pi$ & - & - \\
\hline & 3 & $11 \%$ & $3 \%$ & - & - \\
\hline & $4-5$ & $4 \pi$ & $3 \%$ & - & - \\
\hline & $6-10$ & $24 \%$ & $13 \%$ & - & - \\
\hline & $11-15$ & $17 \%$ & $10 \%$ & - & - \\
\hline & $16-20$ & $15 \%$ & $9 \%$ & - & - \\
\hline & over 20 & $13 \%$ & $58 \%$ & - & - \\
\hline \multirow{10}{*}{$\begin{array}{l}\text { Yeas } \\
\text { exporting }\end{array}$} & 0 & $0 \times$ & $4 \%$ & 0.0760 & 0.2042 \\
\hline & 1 & $6 \%$ & $7 \%$ & - & - \\
\hline & 2 & $11 \%$ & $7 \%$ & - & - \\
\hline & 3 & $11 \%$ & $7 \%$ & - & - \\
\hline & 4 & $0 \%$ & $9 \%$ & - & - \\
\hline & 5 & $4 x$ & $8 \%$ & - & - \\
\hline & 6-10 & $24 \%$ & $23 \%$ & - & - \\
\hline & $11-15$ & $17 \%$ & $8 \%$ & - & - \\
\hline & $16-2$ & $15 \%$ & $13 \%$ & - & - \\
\hline & over 20 & $13 \%$ & $15 \%$ & - & - \\
\hline \multirow[t]{4}{*}{ Bmployees } & Less than 20 & $11 \%$ & $14 \%$ & 0,4208 & 0.0868 \\
\hline & $20-99$ & $22 \%$ & $22 x$ & - & - \\
\hline & $100-499$ & $30 \%$ & $32 \%$ & - & - \\
\hline & 500 or mare & $37 \%$ & $31 \%$ & - & - \\
\hline \multirow{4}{*}{$\begin{array}{l}\text { Foreign } \\
\text { ownership }\end{array}$} & None & $38 \%$ & $74 \%$ & 0.0000 & 03248 \\
\hline & Leas than $20 \%$ & $4 \%$ & $1 \%$ & - & - \\
\hline & $20-50 \%$ & $4 \%$ & $7 \%$ & - & - \\
\hline & Greater then $50 \%$ & $55 \%$ & $17 \%$ & - & - \\
\hline \multirow{7}{*}{$\begin{array}{l}\text { Total Rand } \\
\text { salea }\end{array}$} & $1-200 \mathrm{~K}$ & $6 \%$ & $5 \%$ & 0.0000 & 0.4593 \\
\hline & $>200 \mathrm{~K}-1 \mathrm{M}$ & $9 \%$ & $6 \%$ & - & - \\
\hline & $>1 M-2 M$ & $2 \%$ & $6 \%$ & - & - \\
\hline & $>2 \mathrm{M} \cdot 10 \mathrm{M}$ & $19 \%$ & $18 \%$ & - & - \\
\hline & $>10 M-20 M$ & $13 \%$ & $10 \%$ & - & - \\
\hline & $>20 \mathrm{M}$ & $50 \%$ & $51 \%$ & - & - \\
\hline & Unknown & $2 \%$ & $5 \%$ & - & - \\
\hline \multirow{6}{*}{$\begin{array}{l}\% \text { of toul } \\
\text { salos }\end{array}$} & None & $4 \%$ & $13 \%$ & 0.0000 & 0.9228 \\
\hline & $1-5 \%$ & $4 \%$ & $34 \%$ & - & - \\
\hline & $6-10 \%$ & $0 \%$ & $12 \%$ & - & - \\
\hline & $11-20 \%$ & $8 \%$ & $13 \%$ & - & - \\
\hline & $21-50 \%$ & $11 \%$ & $13 \%$ & - & - \\
\hline & grealeer then $50 \%$ & $74 \%$ & $14 \%$ & - & - \\
\hline \multirow{2}{*}{$\begin{array}{l}\text { Age of } \\
\text { manager }\end{array}$} & Lews then 50 & $77 \%$ & $34 \%$ & 0.0000 & 0.3083 \\
\hline & SO ox more & $23 \%$ & $66 \%$ & - & - \\
\hline \multirow{2}{*}{$\begin{array}{l}\text { Country } \\
\text { bown }\end{array}$} & Sing $S A$ & $42 \%$ & $59 \%$ & 0.0158 & 0.1251 \\
\hline & Other & $58 \%$ & $41 \%$ & - & - \\
\hline \multirow{3}{*}{$\begin{array}{l}\text { Yean } \\
\text { reaident } \\
\text { abroad }\end{array}$} & None & $28 \%$ & $40 \%$ & 0.0000 & 0.2316 \\
\hline & Leas than one & $6 \%$ & $0 \%$ & - & - \\
\hline & 1 or more & $66 \%$ & $60 \%$ & - & - \\
\hline \multirow{4}{*}{$\begin{array}{l}\text { Business } \\
\text { tripe }\end{array}$} & None & $0 \%$ & $8 x$ & 0.0019 & 0.1997 \\
\hline & 1 & $0 \%$ & $6 \%$ & - & - \\
\hline & $2-4$ & $13 \%$ & $25 \%$ & - & - \\
\hline & Sor more & $87 \%$ & $61 \%$ & - & - \\
\hline
\end{tabular}




\section{Results}

\section{Perceived reasons for exporting}

Managerial, organizational and environmental factors emerged as important reasons for exporting in both studies. Over $75 \%$ of each sample indicated that strong managerial goals, increased potential profits and potential economies of scale were important. A large proportion of each sample also indicated that enquiries from overseas firms were important. Not tested by Elliot \& Krasnostein (1990), enquiries from distributors or agents were considered important by $78 \%$ of the South African sample.

Compared to the Singaporean sample, more South African firms perceive utilization of excess capacity, expansion into neighbouring countries, enquiries from industry associates and export incentives from local government to be important. Only $13 \%$ of respondents indicated that excess capacity was not a reason for exporting. An owner/managers trip to a foreign country, export incentives from foreign governments, following competitors and improving the firms image emerged as much less important reasons to export in South Africa.

\section{Perceived information source importance}

Results for the six items measured in both studies reveal different information source usage and importance. Fewer South African firms perceived each item measured as an important information source and $32 \%$ did not use an information source, on average.

\section{Secondary information sources}

Governmental relations and sources of information can be of primary importance to successful developing nation business strategies (see Austin, 1990: espec. 147-184). Elliot \& Krasnostein suggested that

'it may be the case that authoritative and respected government sources in an export-intensive manufacturing economy are perceived as a more important information source than are their counterparts in economies such as Canada, Australia, New Zealand, Argentina and South Africa, where traditional export culture has developed around agricultural and mineral commodities' (1990: 22).

\begin{tabular}{|c|c|c|c|c|c|c|c|c|c|}
\hline & \multicolumn{3}{|c|}{ Singapore } & \multicolumn{3}{|c|}{ South Africa } & \multirow[b]{2}{*}{$\mathbf{n}$} & \multirow[b]{2}{*}{ Prob of X2 } & \multirow[b]{2}{*}{ Cramer's V } \\
\hline & Important & Unimportant & Did not occur & Important & Unimportant & Did not occur & & & \\
\hline Close proximity to ports & - & - & - & $37 \%$ & $34 \%$ & $30 \%$ & 307 & - & - \\
\hline Competition in Singapore & $44 \%$ & $24 \%$ & $31 \%$ & - & - & - & - & - & - \\
\hline Enquiries from barks & $7 \%$ & $32 \%$ & $61 \%$ & - & - & - & - & - & - \\
\hline Enquiries from distributors/agents & - & - & - & $78 \%$ & $13 \%$ & $9 \%$ & 312 & - & - \\
\hline Enquiries from industry associates & $27 \%$ & $32 \%$ & $41 \%$ & $48 \%$ & $20 \%$ & $32 \%$ & 307 & 0.0076 & 0.2209 \\
\hline Enquiries from overseas firms & $84 \%$ & $9 \%$ & $7 \%$ & $83 \%$ & $11 \%$ & $6 \%$ & 311 & 0.8681 & 0.0376 \\
\hline $\begin{array}{l}\text { Enquiries from the Singaporean Ministry } \\
\text { of Trade }\end{array}$ & $27 \%$ & $41 \%$ & $32 \%$ & - & - & - & - & - & - \\
\hline $\begin{array}{l}\text { Enquiries from the Singaporean Trade } \\
\text { Commissioners }\end{array}$ & $27 \%$ & $36 \%$ & $36 \%$ & - & - & - & - & - & - \\
\hline $\begin{array}{l}\text { Export incentives from foreign } \\
\text { government }\end{array}$ & $27 \%$ & $28 \%$ & $46 \%$ & $11 \%$ & $21 \%$ & $69 \%$ & 302 & 0.0020 & 0.2492 \\
\hline Export incentives from local government & $49 \%$ & $27 \%$ & $25 \%$ & $76 \%$ & $17 \%$ & $7 \%$ & 311 & 0.0002 & 0.2952 \\
\hline Export improve image of firm* & $59 \%$ & $26 \%$ & $1 \%$ & $43 \%$ & $42 \%$ & $12 \%$ & 319 & 0.0004 & 0.2786 \\
\hline Fellow competitors & $48 \%$ & $32 \%$ & $21 \%$ & $16 \%$ & $43 \%$ & $42 \%$ & 308 & 0.0000 & 0.3524 \\
\hline Increased profit potential & $90 \%$ & $2 \%$ & $8 \%$ & $77 \%$ & $17 \%$ & $6 \%$ & 307 & 0.1178 & 0.1463 \\
\hline Overseas travel opportunities & $21 \%$ & $44 \%$ & $35 \%$ & - & - & - & - & - & - \\
\hline $\begin{array}{l}\text { Owner's/manager's trip to foreign } \\
\text { country }\end{array}$ & $78 \%$ & $11 \%$ & $11 \%$ & $42 \%$ & $34 \%$ & $24 \%$ & 307 & 0.0000 & 0.3700 \\
\hline Poxential economies of scale & $73 \%$ & $11 \%$ & $17 \%$ & $77 \%$ & $17 \%$ & $6 \%$ & 307 & 0.0514 & 0.1723 \\
\hline Received an unsolicited order* & $37 \%$ & $18 \%$ & $25 \%$ & $38 \%$ & $28 \%$ & $34 \%$ & 301 & 0.4989 & 0.0834 \\
\hline Saturated local market & $50 \%$ & $20 \%$ & $30 \%$ & $47 \%$ & $30 \%$ & $23 \%$ & 310 & 0.2212 & 0.1228 \\
\hline Strong managerial goals for expansion & $75 \%$ & $11 \%$ & $0 \%$ & $85 \%$ & $9 \%$ & $6 \%$ & 316 & 0.1337 & 0.1419 \\
\hline $\begin{array}{l}\text { Successful expansion into neighbouring } \\
\text { countries }\end{array}$ & $29 \%$ & $24 \%$ & $47 \%$ & $64 \%$ & $17 \%$ & $19 \%$ & 311 & 0.0000 & 0.3623 \\
\hline Unique product & $63 \%$ & $13 \%$ & $24 \%$ & $48 \%$ & $25 \%$ & $27 \%$ & 310 & 0.0500 & 0.1731 \\
\hline Utilization of excess capacity & $29 \%$ & $26 \%$ & $43 \%$ & $73 \%$ & $16 \%$ & $13 \%$ & 311 & 0.0000 & 0.4300 \\
\hline
\end{tabular}




\begin{tabular}{|c|c|c|c|c|c|c|c|c|c|}
\hline \multirow[b]{2}{*}{ Sources } & \multicolumn{3}{|c|}{ Singapore } & \multicolumn{4}{|c|}{ South Africa } & \multirow[b]{2}{*}{ Prob of $\times 2$} & \multirow[b]{2}{*}{ Cramer's V } \\
\hline & Important & Unimportant & Did not occur & Important & Unimportant & Did not occur & $\mathbf{n}$ & & \\
\hline Africa South of the Sahara & - & - & - & $31 \%$ & $15 \%$ & $55 \%$ & 276 & - & - \\
\hline Banks & $58 \%$ & 429 & DNR & $37 \%$ & $24 \%$ & $39 \%$ & 277 & 0.6656 & 0.0306 \\
\hline Economic Development Bank & $91 \%$ & $9 \%$ & DNR & - & - & - & - & - & - \\
\hline Economist Country Report & - & - & - & $31 \%$ & $19 \%$ & $50 \%$ & 272 & - & - \\
\hline Firm's Market Research & - & - & - & $89 \%$ & $4 \%$ & $7 \%$ & 302 & - & - \\
\hline Foreign Government Bodies & $65 \%$ & $35 \%$ & DNR & - & - & - & - & - & - \\
\hline Industry Trade Associations & $77 \%$ & $23 \%$ & DNR & $14 \%$ & $22 \%$ & $63 \%$ & 272 & 0.0000 & 0.3850 \\
\hline \multicolumn{10}{|l|}{ Ministry/Department of Trade and } \\
\hline Industry & $83 \%$ & $17 \%$ & DNR & $61 \%$ & $24 \%$ & $14 \%$ & 298 & 0.0625 & 0.1317 \\
\hline Other local exporters & $67 \%$ & $33 \%$ & DNR & $41 \%$ & $19 \%$ & $40 \%$ & 274 & 0.8800 & 0.0107 \\
\hline Personal business contacts & - & - & - & $94 \%$ & $5 \%$ & $1 \%$ & 299 & - & - \\
\hline Potential foreign buyers or agents & $90 \%$ & $10 \%$ & DNR & $89 \%$ & $4 \%$ & $7 \%$ & 293 & 0.0963 & 0.1176 \\
\hline Representatives of foreign market in SA & - & - & - & $27 \%$ & $21 \%$ & $52 \%$ & 270 & - & - \\
\hline SAFTO & - & - & - & $72 \%$ & $23 \%$ & $5 \%$ & 311 & - & - \\
\hline $\begin{array}{l}\text { Trade Commissioner/South African } \\
\text { representative }\end{array}$ & $71 \%$ & $29 \%$ & DNR & $49 \%$ & $23 \%$ & $28 \%$ & 298 & 0.6450 & 0.0326 \\
\hline Trade Fairs & - & - & - & $54 \%$ & $23 \%$ & $23 \%$ & 289 & - & - \\
\hline Trade Journals & - & - & - & $58 \%$ & $21 \%$ & $21 \%$ & 290 & - & - \\
\hline World Bank Reports & - & - & - & $15 \%$ & $22 \%$ & $63 \%$ & 269 & - & - \\
\hline
\end{tabular}

Note: Elliot \& Krasnostein (1990) did not report frequencies for information sources. Statistical tests compare proportional responses to each statement (percentages grossed up for RSA)

Government information generally has been reported as less important (Cavusgil, 1983; O'Rourke, 1985; Pavord \& Bogard, 1975).

Trade commissioners were considered important by less than half of the South African sample. Foreign trade representatives were not used by over half of the sample and only $56 \%$ of those who used this source reported that it was important. While Elliot \& Krasnostein (1990: 22) reported that 83\% of the Singaporean sample felt the Ministry of Trade and Industry was at least somewhat important, the current research indicates that $61 \%$ of the sample found Department of Trade and Industry information important.

Industry trade association information also appears to be much less important than reported for Singapore by Elliot \& Krasnostein (1990: 15). Only 14\% of the South African sample claimed that industry trade associations are important and $63 \%$ report not using this source. Altogether $75 \%$ did not use the National Productivity Institute and only $34 \%$ of those who did found the information provided to be important. The findings confirm past research indicating industry trade associations are considered important information sources by only $20 \%$ to $30 \%$ of companies (Pavord \& Bogard, 1975).

Cavusgil (1983) and Reid (1984) suggested that exporters may not rely heavily on published secondary data. Less than half of the respondents in the current research consult World Bank reports, Africa South of the Sahara or Economist country reports and about half of those using these sources considered them to provide important information.

\section{Primary information sources}

Primary information sources are much more important than secondary sources to South African exporters, confirming prior research (Keng \& Jiuan, 1989; Tseng \& Yu, 1991). Altogether $83 \%$ of the sample conducted proprietary marketing research in foreign markets and $96 \%$ of those who did found it useful. Trade fairs and trade journals - perhaps more widely acknowledged as vehicles for direct selling in foreign markets - provided useful information to over $70 \%$ of those utilizing these sources. The findings support the unimportance of banks as an information source.

Contrary to previous findings concerning the unimportance of institutional information sources (see Elliot \& Krasnostein, 1990: 22), SAFTO was considered to be an important information source by $72 \%$ of the sample. This result needs to be considered in the context of the source of the sample (paid SAFTO members) and the extensive range of informational services offered by SAFTO (internationally accredited training courses in all aspects of exporting, primary research for clients in foreign markets, secondary research information on foreign markets and culture and trade fairs for companies, industries and the government). It is unclear which of these individual services was considered as an important information source by the respondents.

Personal business contacts and potential foreign buyers or agents were considered important by almost every respondent. Information from other local exporters was considered important by only $41 \%$ of the sample - although $68 \%$ of those who use this source consider the information provided to be important. 


\begin{tabular}{|c|c|c|c|c|c|c|c|c|c|c|c|}
\hline \multirow[b]{3}{*}{ Problems } & \multicolumn{4}{|c|}{ Singapore } & \multicolumn{4}{|c|}{ South Africa } & \multirow{3}{*}{$\mathbf{n}$} & \multirow{3}{*}{$\begin{array}{r}\text { Prob of } \\
\times 2 \\
\end{array}$} & \multirow{3}{*}{$\begin{array}{l}\text { Cramer's } \\
\text { V }\end{array}$} \\
\hline & $\begin{array}{l}\text { Major } \\
\text { limitatio }\end{array}$ & Minor & No & Does not & Major & Minor & No & $\begin{array}{c}\text { Does } \\
\text { not }\end{array}$ & & & \\
\hline & n 1 & limitation l & limitation & apply 1 & limitation 1 & limitation 1 & limitation & apply & & & \\
\hline $\begin{array}{l}\text { Ability to offer competitive credit } \\
\text { terms }\end{array}$ & $19 \%$ & $46 \%$ & $15 \%$ & $19 \%$ & - & - & - & - & - & - & - \\
\hline $\begin{array}{l}\text { Difficulty in handling export } \\
\text { documentation }\end{array}$ & $2 \%$ & $10 \%$ & $48 \%$ & $40 \%$ & $3 \%$ & $19 \%$ & $53 \%$ & $26 \%$ & 318 & 0.0820 & 0.1831 \\
\hline $\begin{array}{l}\text { Difficulty in locating satisfactory } \\
\text { foreign agents }\end{array}$ & $29 \%$ & $23 \%$ & $21 \%$ & $27 \%$ & $20 \%$ & $44 \%$ & $18 \%$ & 316 & 0.0164 & 0.2266 & \\
\hline $\begin{array}{l}\text { Difficulty in making contacts in } \\
\text { foreign markets }\end{array}$ & - & - & - & - & $19 \%$ & $39 \%$ & $26 \%$ & $16 \%$ & 317 & - & - \\
\hline $\begin{array}{l}\text { Difficulty in obtaining funds } \\
\text { necessary to expand }\end{array}$ & $14 \%$ & $31 \%$ & $25 \%$ & $31 \%$ & $15 \%$ & $30 \%$ & $28 \%$ & 316 & 0.9446 & 0.0435 & \\
\hline $\begin{array}{l}\text { Difficulty in receiving payment from } \\
\text { foreign markets }\end{array}$ & - & - & - & - & $15 \%$ & $48 \%$ & $25 \%$ & $12 \%$ & 318 & - & - \\
\hline $\begin{array}{l}\text { Difficulty in understanding foreign } \\
\text { business practices }\end{array}$ & - & - & - & - & $7 \%$ & $45 \%$ & $28 \%$ & $20 \%$ & 317 & - & - \\
\hline $\begin{array}{l}\text { Difficulty in meeting foreign } \\
\text { delivery dates }\end{array}$ & $12 \%$ & $39 \%$ & $27 \%$ & $23 \%$ & $7 \%$ & $32 \%$ & $40 \%$ & $22 \%$ & 317 & 0.2077 & 0.1509 \\
\hline Exchange rate fluctations & $23 \%$ & $38 \%$ & $31 \%$ & $8 \%$ & $17 \%$ & $51 \%$ & $26 \%$ & $6 \%$ & 318 & 0.3178 & 0.1327 \\
\hline $\begin{array}{l}\text { Formal franchise agreement with } \\
\text { overseas parent }\end{array}$ & $6 \%$ & $4 \%$ & $14 \%$ & $77 \%$ & - & - & - & - & - & - & - \\
\hline $\begin{array}{l}\text { High freight costs to foreign markets } \\
\text { Inability to find suitable staff for }\end{array}$ & $10 \%$ & $37 \%$ & $37 \%$ & $17 \%$ & $30 \%$ & $50 \%$ & $13 \%$ & $7 \%$ & 318 & 0.0000 & 0.3673 \\
\hline $\begin{array}{l}\text { foreign branch } \\
\text { Inability to meet competitive prices }\end{array}$ & $10 \%$ & $15 \%$ & $25 \%$ & $50 \%$ & $3 \%$ & $14 \%$ & $20 \%$ & $63 \%$ & 316 & 0.1189 & 0.1711 \\
\hline $\begin{array}{l}\text { in foreign market } \\
\text { Inability to modify product for }\end{array}$ & $31 \%$ & $33 \%$ & $17 \%$ & $19 \%$ & $35 \%$ & $39 \%$ & $17 \%$ & $9 \%$ & 314 & 0.2295 & 0.1469 \\
\hline $\begin{array}{l}\text { foreign market tastes } \\
\text { Inability to obtain suitable export }\end{array}$ & $10 \%$ & $17 \%$ & $37 \%$ & $37 \%$ & $5 \%$ & $20 \%$ & $42 \%$ & $33 \%$ & 318 & 0.5017 & 0.1086 \\
\hline manager & $8 \%$ & $14 \%$ & $27 \%$ & $52 \%$ & $2 \%$ & $10 \%$ & $43 \%$ & $44 \%$ & 316 & 0.0402 & 0.2037 \\
\hline Inability to service overseas buyers & $12 \%$ & $26 \%$ & $37 \%$ & $26 \%$ & $7 \%$ & $28 \%$ & $40 \%$ & $25 \%$ & 316 & 0.6807 & 0.0868 \\
\hline $\begin{array}{l}\text { Lack of continuity of orders } \\
\text { Lack of useful information about }\end{array}$ & $21 \%$ & $27 \%$ & $13 \%$ & $39 \%$ & $21 \%$ & $47 \%$ & $23 \%$ & $9 \%$ & 315 & 0.0000 & 0.3670 \\
\hline $\begin{array}{l}\text { foreign markets } \\
\text { Licensing agreement imposed on }\end{array}$ & $27 \%$ & $33 \%$ & $14 \%$ & $27 \%$ & $11 \%$ & $48 \%$ & $28 \%$ & $14 \%$ & 317 & 0.0003 & 0.3043 \\
\hline $\begin{array}{l}\text { overseas product design } \\
\text { Limitation imposed by parent }\end{array}$ & $10 \%$ & $10 \%$ & $14 \%$ & $67 \%$ & - & - & - & - & - & - & - \\
\hline $\begin{array}{l}\text { ompany on marketing plans } \\
\text { imitations from parent company }\end{array}$ & $12 \%$ & $8 \%$ & $19 \%$ & $62 \%$ & $9 \%$ & $10 \%$ & $28 \%$ & $53 \%$ & 315 & 0.4017 & 0.1212 \\
\hline restricting local products & $4 \%$ & $8 \%$ & $15 \%$ & $43 \%$ & - & - & - & - & - & - & - \\
\hline Patent restrictions & $4 \%$ & $15 \%$ & $12 \%$ & $69 \%$ & - & - & - & - & - & - & - \\
\hline olitical problems in foreign markets & - & - & - & - & $13 \%$ & $44 \%$ & $27 \%$ & $16 \%$ & 317 & - & - \\
\hline Political problems in local market & - & - & - & - & $20 \%$ & $48 \%$ & $18 \%$ & $15 \%$ & 318 & - & - \\
\hline anctions & - & - & - & - & $20 \%$ & $40 \%$ & $21 \%$ & $19 \%$ & 318 & - & - \\
\hline $\begin{array}{l}\text { Scarcity of skilled labour in country } \\
\text { Transportation problems in foreign }\end{array}$ & $21 \%$ & $33 \%$ & $25 \%$ & $21 \%$ & $17 \%$ & $33 \%$ & $31 \%$ & $19 \%$ & 317 & 0.7617 & 0.0763 \\
\hline $\begin{array}{l}\text { market } \\
\text { Unwillingness to compete with } \\
\text { affiliated firms in overseas market }\end{array}$ & - & - & - & - & $6 \%$ & $33 \%$ & $41 \%$ & $20 \%$ & 316 & - & - \\
\hline iated firms in overseas market & $6 \%$ & $14 \%$ & $21 \%$ & $60 \%$ & - & - & - & - & - & - & - \\
\hline
\end{tabular}




\section{Perceived problems in exporting}

Few firms reported that the problems presented in the current research were major limitations. Results were comparable for many items presented to both samples. South African firms were marginally less likely to find the 15 problems studied in both surveys to be major limitations, suggesting further that their level of infrastructure and organizational resources committed to exporting characterizes a level of involvement and commitment exceeding the level indicated by their export intensity.

Regardless of firm size, the current sample generally felt exchange rate fluctuations were a minor limitation. The South African sample was less likely to report that the lack of useful information was a limitation. Locating satisfactory foreign agents was a major limitation for $64 \%$ of firms in the current research.

Over half of the South African and Singaporean firms studied reported no problems finding suitable staff for foreign offices. When compared to Singaporean firms, a smaller proportion of the South African sample reported limitations finding staff for a foreign branch but the result was not statistically significant. South African firms were less likely to report problems finding a suitable export manager than Singaporean firms.

The sample reported that the inability to meet foreign competitor pricing was a limitation for most exporters. Given the importance of low value-added commodities and heavy manufactured goods to South African exports, it is not surprising that high freight costs to foreign markets emerge as a limitation to $80 \%$ of the firms studied. Although more firms reported high freight costs to be a limiting factor than any other factor, less than $50 \%$ of the South African firms that perceived meeting foreign delivery dates to be applicable reported this issue to be a limitation. Lack of continuity of orders was noted as a limitation by a larger proportion of South African firms.

In total, $53 \%$ of the current sample reported documentation was not a problem - a result comparable to the Singaporean study.

\section{Statements about exporting}

Perceptions of serving the national interest and enhancing the firm's image in the community were important. Altogether 95\% of the South African sample felt exporting was in the national interest, compared to $76 \%$ in the Singapore sample. Over $70 \%$ of both samples believe exporting increases the firm's prestige, reputation and success.

Over $90 \%$ of both samples indicated that their firm was not too small to export. Elliot \& Krasnostein (1990) reported that high proportions of the Singaporean sample rejected a causal link between small size, high costs or the uniqueness of international marketing when compared to local market and lack of exporting success. Similar results emerge from the current research. South African respondents also rejected the notion that export should only be considered when local opportunities are exhausted and the belief that agents are the major cause of failure in foreign markets.

\section{Discussion and conclusions}

Like their Singaporean counterparts, South African firms are motivated to export by managerial, organizational and environmental forces, perceptions and attitudes. Both samples hold similar beliefs about exporting and reject the notion that export marketing is too different to local marketing to allow them to succeed. However, leaving behind years of economic sanctions and slow economic growth, the South African respondents are motivated by unique situational factors such as the need to fill excess capacity, the availability of export incentives (many subject to reduction under GATT) and expansion into neighbouring countries.

It appears that South African managers may benefit from increased time abroad to make contacts and overcome difficulties understanding foreign culture and business practices. The findings concerning the usefulness of trade fairs as an information source will no doubt cause many firms to reconsider trade show participation.

Both samples place importance on primary sources of information concerning exporting. Personal business contacts and primary market research are considered important by almost all South African respondents. South African exporters are analytical. They consider international marketing research to be as important as domestic marketing research and over two-thirds indicate that frequent foreign market analysis takes place. However, far fewer South African firms find the information sources examined in both studies to be important compared to their Singaporean counterparts. While it may be due to the development of South Africa's export culture around mineral and agricultural exports, additional local research is required to explain why so many South African exporters felt secondary information lacked importance in the current research. Providers of secondary information, such as the Department of Trade and Industry, South African representatives abroad and industry trade associations may benefit from a closer understanding of the services provided to exporters by their Singaporean counterparts. Clearly, there is room for increasing the frequency of use and improving the usefulness of secondary information in South Africa.

Strategies to lessen the impact of exchange rate fluctuations, meet competitive prices, locate satisfactory foreign agents and find useful information appear to require careful consideration by exporters in both nations. Not surprisingly, South Africans are experiencing more problems concerning freight costs and discontinuity of orders. More work is needed to understand the nature of these problems and their influence on South African exporting effectiveness. Logistics is an area where special emphasis is needed.

This study presents some interesting implications for those interested in South African exporting. Managerial leadership, supportive attitudes and extensive exporting experience appear to suggest that these firms feel they can be successful exporters. Governmental and institutional bodies would be well placed to fund future research investigating the situational and environmental influences facing South African exporters so that more effective assistance and increased informational support concerning foreign contacts and culture can be provided. 


\section{Acknowledgement}

The authors thank two anonymous reviewers for comments which improved this manuscript, Mr James McLuckie of the Institute of Marketing Management for bringing the Singaporean research to our attention, and Mrs Rose Blatch and Ms Ali Parry, SAFTO and the South African Institute of Export for their kind assistance.

\section{Roferences}

Aaby, N.E. \& Slater, F.S. 1988. Management influences on export performance: review of the empirical literature, 1978-1988, International Marketing Review, 6(4): 7-26.

Ali, A. \& Swiecz, P.M. 1991. Firm size and export behavior: lessons from the Midwest, Journal of Small Business Management, April: 71-78.

Austin, J.E. 1990. Managing in developing countries: strategic analysis and operating techniques. New York: Free Press.

Axinn, C.N. 1988. Export performance: do managerial perceptions make a difference?, International Marketing Review, 5: 61-71.

Bilkey, W.J. 1978. An attempted integration of the literature on export behavior of firms, Journal of International Business Studies, Spring/Summer: 33-46.

Brooks, M.R. \& Rosson, P.J. 1982. A study of behaviour of small and medium sized manufacturing firms in three Canadian provinces. New York: Preager Publishers.

Cavusgil, S. T. 1980. On the internationalisation process of firms, European Research, 8: 273-281.

Cavusgil, S.T. 1983. Public policy implications of research on the export behavior of firms, Akron Business and Economic Review, 14(2): 16-22.

Cavusgil, S.T. 1984. Differences anong exporting firms based on their degree of internationalisation, Journal of Business Research, 12: 195-208.

Cavusgil, S.T. 1985. Guidelines for export market research, Business Horizons, November/December: 27-33.

Cavusgil, S.T. \& Nevin, J. 1981. International determinants of export marketing behavior: an empirical investigation, Journal of Marketing Research, 18: 114-119.

Cooper, R.A., Hartley, K. \& Harvey, C.R.M. 1970. Export performance and the pressure of demand. New York: Humanities Press.

Cunningham, M.T. \& Spiegel, R.I. 1971. A study in successful exporting, Business Journal of Marketing, 5: 2-21.

Czinkota, M.R. \& Johnston, W.J. 1983. Exporting: Does sales volume make a difference?, Journal of International Business Studies, Spring/Summer: 147-153.

Czinkota, M.R. \& Ronkainen, I.A. 1993. International marketing. New York: Dryden.

Daniels, J. D. 1971. Recent foreign direct manufacturing investment in the United States: an interview study of the decision process. New York: Preager Publishers.

Denis, J. E. \& Depelteau, D. 1985. Market knowledge, diversification, and export expansion, Journal of International Business Studies, Fall: 77-89.

Diamantopoulos, A. \& Inglis, K. 1988. Identifying differences between high and low involvement exporters, International Marketing Review, 5: 52-60.

Dichtl, E., Leibold, M., Koeglmayr, H. G. \& Mueller, S. 1983. The foreign orientation of management as a central construct in export centered decision making processes. $R f m, 10(1), 7-15$.
Elliot, G.R. \& Krasnostein, J.P. 1990. Singapore research and devet opment based manufacturers: their export attitudes and practices, Singapore Marketing Review, V: 1731.

Eshghi, A. 1992. Attitude-behavior inconsistency in exporting, $I n$. ternational Marketing Review, 2(3): 40-61.

Hunt, H.G., Froggatt, J.D. \& Hovell, P.J. 1967. The management of export marketing in engineering industries, British Journal of Marketing, 1: 10-24.

Johnston, W. J. \& Czinkota, M. R. 1982. Managerial motivations a determinants of industrial export behavior. In Czinkota, M.R. \& Tesar, G. (Eds.). Export management: an international contert. New York: Preager Publishers.

Kaynak, E. \& Kothari, V. 1984. Export behaviour of small and me dium-sized manufacturers: some policy guidelines for international marketers, Management International Review, 24(2): 6169.

Keegan, W.J. 1967. Scanning the international business environment: a study of the information acquisition process. Harvard: Harvard Business School.

Keng, K.A. \& Jiuan, T.S. 1989. Differences between small and me dium sized exporting and non-exporting firms: nature or nuttie, International Marketing Review, 6(4): 27-39.

Korth, C.M. 1991. Managerial barriers to U.S. exports, Business Ho. rizons, March-April: 18-26.

Louter, P.J., Ouwerkerk, C. \& Bakker, B.A. 1991. An inquiry into successful exporting, European Journal of Marketing, 25(6): 723.

Morrison, A.J. \& Inkpen, A.C. 1991. An analysis of significant coetributions to the international business literature, Journal of Inter. national Business Studies, 22(1): 143-153:

O'Rourke, A.D. 1985. Differences in exporting practices, attitudes, and problems by the size of the firms, American Journal of Small Business, 2(3): 25-29.

Pavord, W.C. \& Bogard, R.G. 1975. The dynamics of the decision to export, Akron Business and Economic Review, 6: 6-11.

Porter, M. 1980. Competitive strategy: techniques for analyzing industries and competitors. New York: Free Press.

Reid, S. 1984. Information acquisition and export entry decisions in small firms, Journal of Business Research, 12: 101-112.

Snavely, W.P., Weiner, P., Ulbricht, H. \& Enright, E. 1964. Export survey of the greater Hartford area. Starrs: University of Connecticut.

Sood, J.H. \& Adams, P. 1984. Model of management learning styles as a predictor of export behaviour and performance, Journal of Business Research, 12: 169-182.

Tseng, J. Y., \& Yu, C. M. J. 1991. Exports of industrial goods to Europe: the case of the large Taiwanese firms, European Journal of Marketing, 25(9):. 51-63.

Viviers, W., Kroon, J., \& Calof, J. L. 1996. Export bebaviour of South African enterprises: Stages and attitudes towards export, South African Journal of Business management, 27(1/2): 34-42.

Wee Chow Hou. 1993. Economic development of Singapore: some lessons for other countries. Singapore: National University of Singapore.

Welch, L. \& Wiedersheim-Paul, F. 1978. Domestic expansion and the internationalisation process. Paper presented at the Working Paper, Uppsala.

World Bank. 1996. World development report: from plan to market. New York: Oxford University Press. 